\title{
Neurological Manifestations of Hospitalized Patients with COVID-19 \\ in Wuhan, China: a retrospective case series study
}

Ling Mao*, Mengdie Wang*, Shengcai Chen*, Quanwei He*, Jiang Chang*, Candong Hong, Yifan Zhou, David Wang, Yanan $\mathrm{Li}^{\dagger}$, Huijuan $\mathrm{Jin}^{\dagger}$, Bo $\mathrm{Hu}^{\dagger}$

Department of neurology (Prof. LM, MW Ph.D., SC Ph.D., Prof. QH, Prof. YL,

Prof. HJ, Prof. BH), Union hospital, Tongji medical college, Huazhong university of science and technology, Wuhan, 430022, China;

Department of Epidemiology and Biostatistics, Key Laboratory for Environment and Health, School of Public Health (Prof. JC), Tongji medical college, Huazhong university of science and technology, Wuhan, 430022, China;

Neurovascular Division, Department of Neurology, Barrow Neurological Institute/Saint Joseph Hospital Medical Center Phoenix, AZ 85013 USA (Prof. DW)

${ }^{*}$ Contributed equally

${ }^{\dagger}$ Correspondence authors

Correspondence to:

Prof. Bo Hu, Department of neurology, Union hospital, Tongji medical college,

Huazhong university of science and technology, Wuhan, 430022, China

hubo@mail.hust.edu.cn

Or Prof. Huijuan Jin, Department of Neurology, Union hospital, Tongji medical college, Huazhong university of science and technology, Wuhan, 430022, China jinhuijuan1983@163.com 
medRxiv preprint doi: https://doi.org/10.1101/2020.02.22.20026500; this version posted February 25, 2020. The copyright holder for this preprint (which was not certified by peer review) is the author/funder, who has granted medRxiv a license to display the preprint in All rights reserved. No reuse allowed without permission.

Or Prof. Yanan Li, Department of Neurology, Union hospital, Tongji medical college,

Huazhong university of science and technology, Wuhan, 430022, China

liyn@,mail.hust.edu.cn 
medRxiv preprint doi: https://doi.org/10.1101/2020.02.22.20026500; this version posted February 25, 2020. The copyright holder for this preprint (which was not certified by peer review) is the author/funder, who has granted medRxiv a license to display the preprint in

All rights reserved. No reuse allowed without permission.

\section{ABSTRACT \\ OBJECTIVE}

To study the neurological manifestations of patients with coronavirus disease 2019 (COVID-19).

\section{DESIGN}

Retrospective case series

\section{SETTING}

Three designated COVID-19 care hospitals of the Union Hospital of Huazhong University of Science and Technology in Wuhan, China.

\section{PARTICIPANTS}

Two hundred fourteen hospitalized patients with laboratory confirmed diagnosis of severe acute respiratory syndrome from coronavirus 2 (SARS-CoV-2) infection. Data were collected from 16 January 2020 to 19 February 2020.

\section{MAIN OUTCOME MEASURES}

Clinical data were extracted from electronic medical records and reviewed by a trained team of physicians. Neurological symptoms fall into three categories: central nervous system (CNS) symptoms or diseases (headache, dizziness, impaired consciousness, ataxia, acute cerebrovascular disease, and epilepsy), peripheral nervous system (PNS) symptoms (hypogeusia, hyposmia, hypopsia, and neuralgia), and skeletal muscular symptoms. Data of all neurological symptoms were checked by two trained neurologists.

\section{RESULTS}

Of 214 patients studied, $88(41.1 \%)$ were severe and $126(58.9 \%)$ were non-severe patients. Compared with non-severe patients, severe patients were older $(58.7 \pm 15.0$ years vs $48.9 \pm 14.7$ years), had more underlying disorders (42 [47.7\%] vs 41 
medRxiv preprint doi: https://doi.org/10.1101/2020.02.22.20026500; this version posted February 25, 2020. The copyright holder for this preprint (which was not certified by peer review) is the author/funder, who has granted medRxiv a license to display the preprint in All rights reserved. No reuse allowed without permission.

[32.5\%]), especially hypertension (32 [36.4\%] vs 19 [15.1\%]), and showed less typical symptoms such as fever (40 [45.5\%] vs 92 [73\%]) and cough (30 [34.1\%] vs 77 [61.1\%]). Seventy-eight (36.4\%) patients had neurologic manifestations. More severe patients were likely to have neurologic symptoms (40 [45.5\%] vs 38 [30.2\%]), such as acute cerebrovascular diseases (5 [5.7\%] vs 1 [0.8\%]), impaired consciousness (13 [14.8\%] vs $3[2.4 \%])$ and skeletal muscle injury (17 [19.3\%] vs 6 [4.8\%]).

\section{CONCLUSION}

Compared with non-severe patients with COVID-19, severe patients commonly had neurologic symptoms manifested as acute cerebrovascular diseases, consciousness impairment and skeletal muscle symptoms. 
medRxiv preprint doi: https://doi.org/10.1101/2020.02.22.20026500; this version posted February 25, 2020. The copyright holder for this preprint (which was not certified by peer review) is the author/funder, who has granted medRxiv a license to display the preprint in

All rights reserved. No reuse allowed without permission.

\section{Introduction}

In December 2019, many unexplained pneumonia cases occurred in Wuhan, China, and has rapidly spread to other parts of China, then to Europe, North America and Asia. This outbreak was confirmed to be caused by a novel coronavirus (2019 novel coronavirus, 2019-nCoV) [1]. 2019-nCov was reported to have symptoms resembled that of severe acute respiratory syndrome coronavirus (SARS-CoV) in 2003 [2]. Both shared the same receptor, angiotensin-converting enzyme 2 (ACE2) [3]. Therefore, this virus was named SARS-CoV-2, and recently WHO named it coronavirus disease 2019 (COVID-19). Until February $21^{\text {th }} 2020$, there were 75569 confirmed cases of COVID-19 and 2239 deaths in China [4].

Coronaviruses can cause multiple systemic infections or injuries in various animals [5]. However, some of them can adapt fast and cross the species barrier, such as in the cases of SARS-CoV and Middle East respiratory syndrome-CoV (MERS-CoV), causing epidemics or pandemics. Infection in human often leads to severe clinical symptoms and high mortality [6]. As for COVID-19, several studies have described clinical manifestations including respiratory symptoms, myalgia and fatigue. COVID-19 also has characteristic laboratory findings and lung CT abnormalities [7]. However, it has not been reported that patients with COVID-19 had any neurological manifestations. Here, we would like to report the characteristic neurological manifestation of SARSCoV-2 infection in 78 of 214 patients with laboratory-confirmed diagnosis of COVID-19 and treated at our hospitals, which are located in the epicenter of Wuhan.

\section{Methods}

\section{Study Design and Participants}

This was a retrospective study. Data was reviewed on all patients with COVID-19 from January 16 to February 19, 2020 at three designated COVID-19 care hospitals of 
medRxiv preprint doi: https://doi.org/10.1101/2020.02.22.20026500; this version posted February 25, 2020. The copyright holder for this preprint (which was not certified by peer review) is the author/funder, who has granted medRxiv a license to display the preprint in

All rights reserved. No reuse allowed without permission.

Union Hospital of Huazhong University of Science and Technology. All patients with COVID-19 enrolled in this study were diagnosed according to the WHO interim guideline [8]. Only those cases confirmed by a positive result to real-time reversetranscriptase polymerase-chain-reaction (RT-PCR) assay from throat swab specimens were included in the analysis [9]. Union Hospital, located in the endemic areas of COVID-19 in Wuhan, Hubei Province, is one of the major tertiary healthcare system and teaching hospitals responsible for the treatments for SARS-CoV-2 infection as designated by the government. The study was performed in accordance to the principles of the Declaration of Helsinki and was approved by the Research Ethics Committee of Tongji Medical College, Huazhong University of Science and Technology, Wuhan, China. Verbal consent was obtained from patients before the enrollment.

\section{Data Collection}

The demographic characteristics, medical history, symptoms, clinical signs, laboratory findings, chest computed tomographic (CT) scan findings were extracted from electronic medical records. The data were reviewed by a trained team of physicians. Neurological symptoms were categorized into three main areas: central nervous system (CNS) symptoms or disease, peripheral nervous system (PNS) symptoms and muscular symptoms. Acute cerebrovascular disease included ischemic stroke and cerebral hemorrhage diagnosed by head CT. Muscle injury was defined when a patient had myalgia and elevated serum creatine kinase level above 200 U/L [7]. All neurological symptoms were reviewed and confirmed by two trained neurologists. The date of disease onset was defined as the day when the symptom was noticed. The severity of COVID-19 was defined by the international guidelines for community-acquired pneumonia [10]. 
medRxiv preprint doi: https://doi.org/10.1101/2020.02.22.20026500; this version posted February 25, 2020. The copyright holder for this preprint (which was not certified by peer review) is the author/funder, who has granted medRxiv a license to display the preprint in

All rights reserved. No reuse allowed without permission.

Throat swab samples were collected and placed into a collection tube containing preservation solution for the virus [9]. SARS-CoV-2 was confirmed by real-time RTPCR assay using a SARS-CoV-2 nucleic acid detection kit according to the manufacturer's protocol (Shanghai bio-germ Medical Technology Co Ltd).

\section{Statistical Analysis}

Continuous variables were described as means and standard deviations, or medians and interquartile range (IQR) values. Categorical variables were expressed as counts and percentages. Continuous variables were compared by using the unpaired Wilcox rank-sum test. Proportions for categorical variables were compared using the $\chi^{2}$ test. All statistical analyses were performed using R (version 3.3.0) software. The significance threshold was set at a $P<0.05$.

\section{Results}

\section{Demographic and clinical characteristics}

A total of 214 hospitalized patients with confirmed SARS-CoV-2 infection were included in the present analysis. Their demographic and clinical characteristics were shown in Table 1. Their average age was $52.7 \pm 15.5$ years, and 127 (59.3\%) were females. Of these patients, $83(38.8 \%)$ had at least one of the following underlying disorders: hypertension $(51[23.8 \%])$, diabetes $(30$ [14.0\%]), cardiovascular disease (15 $[7.0 \%])$, and malignancy (13 [6.1\%]). The most common symptoms at onset of illness were fever (132 [61.7\%]), dry cough (107 [50.0\%]) and anorexia (68 [31.8\%]). Seventy-eight (36.4\%) patients had nervons system symptoms: CNS (53 [24.8\%]), PNS (19 [8.9\%]) and skeletal muscles (23 [10.7\%]). In patients with CNS symptoms, the most common complaints were dizziness (36 [16.8\%] and headache (28 [13.1\%]). In patients with PNS symptoms, the most common complaints were hypogeusia (12 $[5.6 \%])$ and hyposmia $(11[5.1 \%])$. 
medRxiv preprint doi: https://doi.org/10.1101/2020.02.22.20026500; this version posted February 25, 2020. The copyright holder for this preprint (which was not certified by peer review) is the author/funder, who has granted medRxiv a license to display the preprint in

All rights reserved. No reuse allowed without permission.

According to the diagnostic criteria, 88 (41.1\%) patients were severe and 126 $(58.9 \%)$ patients were non-severe, respectively. The patients with severe infection were significantly older $(58.2 \pm 15.0$ years vs $48.9 \pm 14.7$ years; $P<0.001)$ and more likely to have other underlying disorders (42 [47.7\%] vs $41[32.5 \%], P<0.05)$, especially hypertension (32 [36.4\%] vs 19 [15.1\%], $P<0.001)$, and had less typical symptoms such as fever (40 [45.5\%] vs $92[73 \%], P<0.001)$ and dry cough $(30[34.1 \%]$ vs 77 [61.1\%], $P<0.001)$. Moreover, nervous system symptoms were significantly more common in severe cases as compared with non-severe cases (40 [45.5\%] vs. 38 [30.2\%], $P<0.05)$. They included acute cerebrovascular disease (5 [5.7\%] (4 patients with ischemic stroke and 1 with cerebral hemorrhage who died later from respiratory failure) vs. 1 [0.8\%] (1 patient with ischemic stroke), $P<0.05)$, impaired consciousness $(13[14.8 \%]$ vs. 3 [2.4\%], $P<0.001)$ and muscle injury $(17[19.3 \%]$ vs. $6[4.8 \%]$, $P<0.001)$.

\section{Laboratory findings in severe patients and non-severe patients}

Table 2 showed the laboratory findings in severe and non-severe subgroups. Severe patients had more increased inflammatory response, including higher white blood cell, neutrophil counts, lower lymphocyte counts and more increased C-reaction protein levels compared with those in non-severe patients (white blood cell: median, 5.4 [IQR, 0.1-20.4] vs 4.5 [IQR, 1.8-14.0], $P<0.01$; neutrophil: median, 3.8 [IQR, 0.018.7] vs 2.6 [IQR, 0.7-11.8], $P<0.001$; lymphocyte: median, 0.9 [IQR, 0.1-2.6] vs 1.3 [IQR, 0.4-2.6], $P<0.001$; C-reaction protein: median, 37.1 [IQR, 0.1-212.0] vs 9.4 [IQR, 0.2-126.0], $P<0.001)$. The severe patients had higher D-dimer levels than nonsevere patients (median, 0.9 [IQR, 0.1-20.0] vs 0.4 [IQR, 0.2-8.7], $P<0.001$ ), which was indicative of consumptive coagulation system. In addition, severe patients had multiple organ involvement, such as serious liver (increased lactate dehydrogenase, 
medRxiv preprint doi: https://doi.org/10.1101/2020.02.22.20026500; this version posted February 25, 2020. The copyright holder for this preprint (which was not certified by peer review) is the author/funder, who has granted medRxiv a license to display the preprint in

All rights reserved. No reuse allowed without permission.

alanine aminotransferase and aspartate aminotransferase levels), kidney (increased blood urea nitrogen and creatinine levels) and muscle damage (increased creatinine kinase levels).

\section{Laboratory findings in patients with and without CNS symptoms}

Table 3 showed the laboratory findings of patients with and without CNS symptoms. We found that patients with CNS symptoms had lower lymphocyte, platelet counts and higher blood urea nitrogen levels compared with those without CNS symptoms (lymphocyte: median, 1.0 [IQR, 0.1-2.3] vs 1.2 [IQR, 0.2-2.6], $P<0.05$; platelet: median, 180.0 [IQR, 18.0-564.0] vs 227.0 [IQR, 42.0-583.0], $P<0.01$; blood urea nitrogen: median, 4.5 [IQR, 1.6-48.1] vs 4.1 [IQR, 1.5-19.1], $P<0.05)$. For the severe subgroup, patients with CNS symptoms also had lower lymphocyte, platelet counts and higher blood urea nitrogen levels compared with those without CNS symptoms (lymphocyte: median, 0.7 [IQR, 0.1-1.6] vs 0.9 [IQR, 0.2-2.6], $P<0.01$; platelet: median, 169.0 [IQR, 18.0-564.0] vs 220.0 [IQR, 109.0-576.0], $P<0.05$; blood urea nitrogen: median, 5.0 [IQR, 2.3-48.1] vs 4.4 [IQR, 1.5-19.1], $P<0.05)$. For non-severe subgroup, there were no significant differences in laboratory findings of patients with and without CNS symptoms.

\section{Laboratory findings in patients with and without PNS symptoms}

Table 4 showed the laboratory findings of patients with and without PNS symptoms. We found that there were no significant differences in laboratory findings of patients with PNS and those without PNS. Similar results were also found in the severe subgroup and non-severe subgroup, respectively.

\section{Laboratory findings in patients with and without muscle injury}

Table 5 showed the laboratory findings of patients with and without muscle injury. Compared with the patients without muscle injury, patients with muscle injury had 
medRxiv preprint doi: https://doi.org/10.1101/2020.02.22.20026500; this version posted February 25, 2020. The copyright holder for this preprint (which was not certified by peer review) is the author/funder, who has granted medRxiv a license to display the preprint in

All rights reserved. No reuse allowed without permission.

higher neutrophil counts, lower lymphocyte counts and higher C-reactive protein levels, D-dimer levels (neutrophil: median, 4.3 [IQR, 0.9-18.7] vs 2.9 [IQR, 0.0-13.0], $P<0.05$; lymphocyte: median, 0.9 [IQR, 0.1-2.6] vs 1.2 [IQR, 0.1-2.6], $P<0.01$; C-reaction protein: median, 56.0 [IQR, 0.1-212.0] vs 11.1 [IQR, 0.1-204.5], $P<0.001$; Ddimer: median, 1.3 [IQR, 0.2-20.0] vs 0.5 [IQR, 0.1-20.0]). The abnormalities were manifestation of increased inflammatory response and blood coagulation function. In addition, we found that patients with muscle injury had multi-organ damage including more serious liver (increased lactate dehydrogenase, alanine aminotransferase and aspartate aminotransferase levels), and kidney (increased blood urea nitrogen and creatinine levels) abnormalities.

For the severe subgroup, patients with muscle injury had increased inflammatory response (decreased lymphocyte counts and increased C-reactive protein levels), and more serious liver (increased lactate dehydrogenase, alanine aminotransferase and aspartate aminotransferase levels), kidney (increased creatinine levels) and muscle damage (increased creatinine kinase levels). For non-severe subgroup, patients with muscle injury only had higher C-reactive protein and creatinine kinase levels compared with those without muscle injury.

\section{Discussion}

This is the first report on detailed neurologic manifestations of the hospitalized patients with COVID-19. As of February 19, 2020, of 214 patients included in this study, $88(41.1 \%)$ were severe and $126(58.9 \%)$ were non-severe. Of these, 78 (36.4\%) had various neurologic manifestations involved CNS, PNS and skeletal muscles. Compared with non-severe patients, severe patients were older and had more hypertension but less with typical symptoms such as fever and cough. Severe patients were more likely to develop neurological symptoms, especially acute cerebrovascular 
medRxiv preprint doi: https://doi.org/10.1101/2020.02.22.20026500; this version posted February 25, 2020. The copyright holder for this preprint (which was not certified by peer review) is the author/funder, who has granted medRxiv a license to display the preprint in

All rights reserved. No reuse allowed without permission.

disease, conscious disturbance and muscle injury. Therefore, for patients with

COVID-19, we need to pay close attention to their neurologic manifestations, especially for those with severe infectons, which may have contributed to their demise. Moreover, during the epidemic period of COVID-19, when seeing patients with these neurologic manifestations, doctors should consider SARS-CoV-2 infection as a differential diagnosis so to avoid delayed diagnosis or misdiagnosis and prevention of transmission.

Recently, ACE2 is identified as the functional receptor for SARS-CoV-2 [3], which is present in multiple human organs, including nervous system and skeletal muscle [11]. The expression and distribution of ACE2 remind us that the SARS-CoV-2 may cause some neurological symptoms through direct or indirect mechanisms.

Neurological injury has been confirmed in the infection of other coronavirus such as in SARS-CoV and MERS-CoV. The researchers detected SARS-CoV nucleic acid in the cerebrospinal fluid of those patients and also in their brain tissue on autopsy [1213].

CNS symptoms were the main form of neurological injury in patients with COVID19 in this study. The pathological mechanism may be from the CNS invasion of SARS-CoV-2, similar to SARS and MERS virus. Like other respiratory viruses, SARS-COV-2 may enter the CNS through the hematogenous or retrograde neuronal route. The latter can be supported by the fact that some patients in this study had hyposmia. We also found that the lymphocyte counts were lower for patients with CNS symptoms than without CNS symptoms. This phenomenon may be indicative of the immunosuppression in COVID-19 patients with CNS symptoms, especially in the severe subgroup. Moreover, we found severe patients had higher D-dimer levels than 
medRxiv preprint doi: https://doi.org/10.1101/2020.02.22.20026500; this version posted February 25, 2020. The copyright holder for this preprint (which was not certified by peer review) is the author/funder, who has granted medRxiv a license to display the preprint in

All rights reserved. No reuse allowed without permission.

that of non-severe patients. This may be the reason why severe patients are more likely to develop cerebrovascular disease.

Consistent with the previous studies [7] muscle symptom was also common in our study. We speculate that the symptom was due to skeletal muscle injury, as confirmed by elevated creatine kinase levels. We found that patients with muscle symptoms had higher creatine kinase and lactate dehydrogenase levels than those without muscle symptoms. Furthermore, creatine kinase and lactate dehydrogenase levels in severe patients were much higher than those of none-severe patients. This injure could be related to ACE2 in skeletal muscle [14]. However, SARS-CoV, using the same receptor, was not detected in skeletal muscle by post-mortem examination [15]. Therefore, whether SARS-CoV-2 infects skeletal muscle cells by binding with ACE2 requires to be further studied. One other reason was the infection-mediated harmful immune response that caused the nervous system abnormalities. Significantly elevated pro-inflammatory cytokines in serum may cause muscle damage.

This study has several limitations. First, only 214 patients were studied, which could cause biases in clinical observation. It would be better to include more patients from Wuhan, other cities in China, and even other countries. Second, all data were abstracted from the electronic medical records, certain patients with neurological problem might not be captured if their neurological symptoms were too mild, such as with hypogeusia and hyposmia . Third, because most patients were still hospitalized and information regarding clinical outcomes was unavailable at the time of analysis, it was difficult to assess the effect of these neurologic manifestations on their outcome, and continued observations of the natural history of disease are needed.

In conclusion, SARS-CoV-2 may infect nervous system, skeletal muscle as well as respiratory tract. In those with severe infection, neurological involvement is more 
medRxiv preprint doi: https://doi.org/10.1101/2020.02.22.20026500; this version posted February 25, 2020. The copyright holder for this preprint (which was not certified by peer review) is the author/funder, who has granted medRxiv a license to display the preprint in

All rights reserved. No reuse allowed without permission.

likely, which includes acute cerebrovascular diseases, conscious disturbance and skeletal muscle injury. Involvement of the nervous system carries a poor prognosis. Their clinical conditions may worsen and patients may die soon. Therefore, for patient with COVID19, physicians should pay close attention to any neurologic manifestations in addition to the symptoms of respiratory system.

\section{Funding}

This work was supported by the National Key Research and Development Program of China (No. 2018YFC1312200 to BH), the National Natural Science Foundation of China (No. 81820108010 to BH, No.81974182 to LM, No.81671147 to JHJ) and Major refractory diseases pilot project of clinical collaboration with Chinese \& Western Medicine (SATCM-20180339).

\section{Reference}

1. Zhu N, Zhang D, Wang W, et al. A novel coronavirus from patients with pneumonia in China. N Engl J Med 2020; 20:382-8. doi:10.1056/NEJMoa2001017

2. Zhou P, Yang XL, Wang XG, et al. A pneumonia outbreak associated with a new coronavirus of probable bat origin. Nature 2020; published online 3 February. doi:10.1038/s41586-020-2012-7

3. Zhao Y, Zhao Z, Wang Y, et al. Single-cell RNA expression profiling of ACE2, the putative receptor of Wuhan 2019-nCov. bioRxiv 2020, published online 26 January. doi: 10.1101/2020.01.26.919985.

4. WHO. Coronavirus disease 2019 (COVID-19) Situation Report-32. January, 2020. https://www.who.int/docs/default-source/coronaviruse/situation-reports/20200221-sitrep-32-covid-19.pdf?sfvrsn=4802d089_2 (accessed Feb 21, 2020). 
medRxiv preprint doi: https://doi.org/10.1101/2020.02.22.20026500; this version posted February 25, 2020. The copyright holder for this preprint (which was not certified by peer review) is the author/funder, who has granted medRxiv a license to display the preprint in

All rights reserved. No reuse allowed without permission.

5. Su S, Wong G, Shi W, et al. Epidemiology, genetic recombination, and pathogenesis of coronaviruses. Trends Microbiol 2016; 24:490-502.

doi:10.1016/j.tim.2016.03.003

6. WHO. Middle East respiratory syndrome coronavirus (MERS-CoV). November, 2019. https://www.who.int/emergencies/mers-cov/en/ (accessed Jan 19, 2020).

7. Guan WJ, Ni ZY, Hu Y, et al. Clinical characteristics of 2019 novel coronavirus infection in China. medRxiv 2020, published online 9 February. doi:10.1101/2020.02.06.20020974.

8. WHO. Clinical management of severe acute respiratory infection when Novel coronavirus (nCoV) infection is suspected: interim guidance. January, 2020. https://www.who.int/internal-publications-detail/clinical-management- of-severeacute-respiratory-infection-when-novel-coronavirus-(ncov)-infection-is-suspected (accessed February 5, 2020)

9. Huang C, Wang Y, Li X, et al. Clinical features of patients with 2019 novel coronavirus in Wuhan, China. Lancet 2020; 10223:497-506. doi: 10.1016/S0140$6736(20) 30183-5$

10. Metlay JP, Waterer GW, Long AC, et al. Diagnosis and treatment of adults with community-acquired pneumonia: An official clinical practice guideline of the American Thoracic Society and Infectious Disease Society of America. Am J Respir Crit Care Med 2019; 200:e45-e67. doi:10.1164/rccm.201908-1581ST

11. Hamming, W Timens, MLC Bulthuis, et al. Tissue distribution of ACE2 protein, the functional receptor for SARS coronavirus. A first step in understanding SARS pathogenesis. J Pathol 2004; 203:631-637. doi:10.1002/path.1570 
medRxiv preprint doi: https://doi.org/10.1101/2020.02.22.20026500; this version posted February 25, 2020. The copyright holder for this preprint (which was not certified by peer review) is the author/funder, who has granted medRxiv a license to display the preprint in All rights reserved. No reuse allowed without permission.

12. Marc D, Dominique JF, Élodie B, et al. Human coronavirus: respiratory pathogens revisited as infectious neuroinvasive, neurotropic, and neurovirulent agents. In: Sunit KS, Daniel R. Neuroviral Infections: RNA Viruses and Retroviruses. Florida Boca Raton: CRC press 2013:93-122.

13. Arabi YM, Balkhy HH, Hayden FG, et al. Middle East Respiratory Syndrome. N Engl J Med 2017, 376:584-594. doi:10.1056/NEJMsr1408795

14. Cabello-Verrugio C, Morales MG, Rivera JC, et al. Renin-Angiotensin System: An Old Player with Novel Functions in Skeletal Muscle. Med Res Rev 2015, 35:437-63. doi:10.1002/med.21343

15. Ding Y, He L, Zhang Q, et al. Organ distribution of severe acute respiratory syndrome (SARS) associated coronavirus (SARS-CoV) in SARS patients: implications for pathogenesis and virus transmission pathways. J Pathol 2004; 203:62230. doi:10.1002/path.1560 
medRxiv preprint doi: https://doi.org/10.1101/2020.02.22.20026500; this version posted February 25, 2020. The copyright holder for this preprint (which was not certified by peer review) is the author/funder, who has granted medRxiv a license to display the preprint in All rights reserved. No reuse allowed without permission.

Table 1 Clinical characteristics of patients with COVID-19

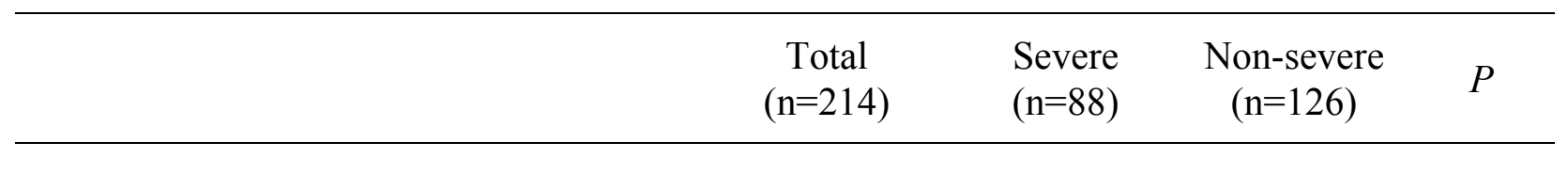

Age (y), means \pm standard deviations

$52.7 \pm 15.5 \quad 58.2 \pm 15.0 \quad 48.9 \pm 14.7$

Age, n $(\%)$

$<0.001$

$<50 \mathrm{y}$

$90(42.1) \quad 24(27.3) \quad 66(52.4)$

$\geq 50 \mathrm{y}$

$124(57.9) \quad 64(72.7) \quad 60(47.6)$

Sex, n $(\%)$

$<0.05$

Female

$127(59.3) \quad 44(50.0) \quad 83(65.9)$

Male

$87(40.7) \quad 44(50.0) \quad 43(34.1)$

Comorbidities, n (\%)

$\begin{array}{lcccc}\text { Any } & 83(38.8) & 42(47.7) & 41(32.5) & <0.05 \\ \text { Hypertension } & 51(23.8) & 32(36.4) & 19(15.1) & <0.001 \\ \text { Diabetes } & 30(14.0) & 15(17.0) & 15(11.9) & 0.287 \\ \text { Cardio cerebrovascular disease } & 15(7.0) & 7(8.0) & 8(6.3) & 0.651 \\ \text { Malignancy } & 13(6.1) & 5(5.7) & 8(6.3) & 0.841 \\ \text { Chronic kidney disease } & 6(2.8) & 2(2.3) & 4(3.2) & 0.694 \\ \text { Pever } & & & & \\ \text { Fical symptoms, n (\%) } & 132(61.7) & 40(45.5) & 92(73.0) & <0.001 \\ \text { Dry cough } & 107(50.0) & 30(34.1) & 77(61.1) & <0.001\end{array}$


medRxiv preprint doi: https://doi.org/10.1101/2020.02.22.20026500; this version posted February 25, 2020. The copyright holder for this preprint (which was not certified by peer review) is the author/funder, who has granted medRxiv a license to display the preprint in All rights reserved. No reuse allowed without permission.
Anorexia
Diarrhea
Pharyngalgia
Abdominal pain
Nervous system symptoms, n (\%)

\begin{tabular}{|c|c|c|c|c|}
\hline Any & $78(36.4)$ & $40(45.5)$ & $38(30.2)$ & $<0.05$ \\
\hline CNS & $53(24.8)$ & $27(30.7)$ & $26(20.6)$ & 0.094 \\
\hline Dizziness & $36(16.8)$ & $17(19.3)$ & $19(15.1)$ & 0.415 \\
\hline Headache & $28(13.1)$ & $15(17.0)$ & $13(10.3)$ & 0.151 \\
\hline Impaired consciousness & $16(7.5)$ & $13(14.8)$ & $3(2.4)$ & $<0.001$ \\
\hline Acute cerebrovascular disease & $6(2.8)$ & $5(5.7)$ & $1(0.8)$ & $<0.05$ \\
\hline Ataxia & $1(0.5)$ & $1(1.1)$ & $0(0.0)$ & NA \\
\hline Epilepsy & $1(0.5)$ & $1(1.1)$ & $0(0.0)$ & NA \\
\hline PNS & $19(8.9)$ & $7(8.0)$ & $12(9.5)$ & 0.691 \\
\hline Hypogeusia & $12(5.6)$ & $3(3.4)$ & $9(7.1)$ & 0.243 \\
\hline Hyposmia & $11(5.1)$ & $3(3.4)$ & $8(6.3)$ & 0.338 \\
\hline Hypopsia & $3(1.4)$ & $2(2.3)$ & $1(0.8)$ & 0.365 \\
\hline Neuralgia & $5(2.3)$ & $4(4.5)$ & $1(0.8)$ & 0.074 \\
\hline Muscle injury & $23(10.7)$ & $17(19.3)$ & $6(4.8)$ & $<0.001$ \\
\hline
\end{tabular}

$\begin{array}{llll}68(31.8) & 21(23.9) & 47(37.3) & <0.05 \\ 41(19.2) & 13(14.8) & 28(22.2) & 0.1730 \\ 31(14.5) & 10(11.4) & 21(16.7) & 0.278 \\ 10(4.7) & 6(6.8) & 4(3.2) & 0.214\end{array}$

$6(6.8)$

$(3.2)$

(1)


medRxiv preprint doi: https://doi.org/10.1101/2020.02.22.20026500; this version posted February 25, 2020. The copyright holder for this preprint (which was not certified by peer review) is the author/funder, who has granted medRxiv a license to display the preprint in All rights reserved. No reuse allowed without permission.

Data are presented as means \pm standard deviations and $\mathrm{n} / \mathrm{N}(\%)$.

Abbreviations: CNS, central nervous symptoms; PNS, peripheral nerves symptoms.

$P$ values indicate differences between severe and non-severe patients. $P<0.05$ was considered statistically significant. 
medRxiv preprint doi: https://doi.org/10.1101/2020.02.22.20026500; this version posted February 25, 2020. The copyright holder for this preprint (which was not certified by peer review) is the author/funder, who has granted medRxiv a license to display the preprint in All rights reserved. No reuse allowed without permission.

Table 2 Laboratory findings of patients with COVID-19

\begin{tabular}{|c|c|c|c|c|}
\hline Median (range) & $\begin{array}{c}\text { Total } \\
(n=214)\end{array}$ & $\begin{array}{l}\text { Severe } \\
(\mathrm{n}=88)\end{array}$ & $\begin{array}{l}\text { Non-severe } \\
\quad(n=126)\end{array}$ & $P$ \\
\hline $\begin{array}{l}\text { White blood cell count, } \\
\times 10^{9} / \mathrm{L}\end{array}$ & $4.9(0.1-20.4)$ & $5.4(0.1-20.4)$ & $4.5(1.8-14.0)$ & $<0.01$ \\
\hline Neutrophil, $\times 10^{9} / \mathrm{L}$ & $3.0(0.0-18.7)$ & $3.8(0.0-18.7)$ & $2.6(0.7-11.8)$ & $<0.001$ \\
\hline Lymphocyte count, $\times 10^{9} / \mathrm{L}$ & $1.1(0.1-2.6)$ & $0.9(0.1-2.6)$ & $1.3(0.4-2.6)$ & $<0.001$ \\
\hline Platelet count, $\times 10^{9} / \mathrm{L}$ & $\begin{array}{l}209.0(18.0- \\
583.0)\end{array}$ & $\begin{array}{l}204.5(18.0- \\
576.0)\end{array}$ & $\begin{array}{l}219.0(42.0- \\
583.0)\end{array}$ & 0.251 \\
\hline C-reactive protein, $\mathrm{mg} / \mathrm{L}$ & $12.2(0.1-212.0)$ & $37.1(0.1-212.0)$ & $9.4(0.4-126.0)$ & $<0.001$ \\
\hline D-dimer, mg/L & $0.5(0.1-20.0)$ & $0.9(0.1-20.0)$ & $0.4(0.2-8.7)$ & $<0.001$ \\
\hline Creatine kinase, U/L & $\begin{array}{l}64.0(8.8- \\
12216.0)\end{array}$ & $\begin{array}{l}83.0(8.8- \\
12216.0)\end{array}$ & $\begin{array}{l}59.0(19.0- \\
1260.0)\end{array}$ & $<0.01$ \\
\hline $\begin{array}{l}\text { Lactate dehydrogenase, } \\
\text { U/L }\end{array}$ & $\begin{array}{l}241.5(2.2- \\
908.0)\end{array}$ & $\begin{array}{l}302.0(2.2- \\
880.0)\end{array}$ & $\begin{array}{l}215.0(2.5- \\
908.0)\end{array}$ & $<0001$ \\
\hline $\begin{array}{l}\text { Alanine aminotransferase, } \\
\text { U/L }\end{array}$ & $\begin{array}{l}26.0(5.0- \\
1933.0)\end{array}$ & $\begin{array}{l}32.5(5.0- \\
1933.0)\end{array}$ & $\begin{array}{l}23.0(6.0- \\
261.0)\end{array}$ & $<0.05$ \\
\hline $\begin{array}{l}\text { Aspartate aminotransfer- } \\
\text { ase, U/L }\end{array}$ & $\begin{array}{l}26.0(8.0- \\
8191.0)\end{array}$ & $\begin{array}{l}34.0(8.0- \\
8191.0)\end{array}$ & $\begin{array}{l}23.0(9.0- \\
244.0)\end{array}$ & $<0.001$ \\
\hline
\end{tabular}

Blood urea nitrogen,

$\mathrm{mmol} / \mathrm{L}$

$$
4.1(1.5-48.1) \quad 4.6(1.5-48.1) \quad 3.8(1.6-13.7) \quad<0.001
$$


medRxiv preprint doi: https://doi.org/10.1101/2020.02.22.20026500; this version posted February 25, 2020. The copyright holder for this preprint (which was not certified by peer review) is the author/funder, who has granted medRxiv a license to display the preprint in All rights reserved. No reuse allowed without permission.

$68.2(35.9-\quad 71.6(35.9-\quad 65.6(39.4-$

Creatinine, $\mu \mathrm{mol} / \mathrm{L}$

$P$ values indicate differences between severe and non-severe patients. $P<0.05$ was considered statistcally significant. 
Table 3 Laboratory findings of COVID-19 patients with CNS symptoms

\begin{tabular}{|c|c|c|c|c|c|c|c|c|c|}
\hline & \multicolumn{3}{|c|}{ Total } & \multicolumn{3}{|c|}{ Severe } & \multicolumn{3}{|c|}{ Non-severe } \\
\hline & $\begin{array}{c}\text { With CNS } \\
\text { symptoms } \\
(\mathrm{n}=53)\end{array}$ & $\begin{array}{l}\text { Without CNS } \\
\text { symptoms } \\
(\mathrm{n}=161)\end{array}$ & $P$ & $\begin{array}{c}\text { With CNS } \\
\text { symptoms } \\
(\mathrm{n}=27)\end{array}$ & $\begin{array}{c}\text { Without CNS } \\
\text { symptoms } \\
(\mathrm{n}=61)\end{array}$ & $P$ & $\begin{array}{c}\text { With CNS } \\
\text { symptoms } \\
(\mathrm{n}=26)\end{array}$ & $\begin{array}{c}\text { Without CNS } \\
\text { symptoms } \\
(\mathrm{n}=100)\end{array}$ & $P$ \\
\hline \multicolumn{10}{|l|}{ Median (range) } \\
\hline White blood cell count, $\times 10^{9} / \mathrm{L}$ & $4.6(0.1-12.5)$ & $4.9(1.8-20.4)$ & 0.582 & $5.3(0.1-12.5)$ & $5.5(1.9-20.4)$ & 0.769 & $4.1(2.4-11.0)$ & $4.6(1.8-14.0)$ & 0.397 \\
\hline Neutrophil, $\times 10^{9} / \mathrm{L}$ & $2.6(0.0-10.9)$ & $3.1(0.7-18.7)$ & 0.413 & $3.8(0.0-10.9)$ & $3.6(0.7-18.7)$ & 1.000 & $2.2(0.9-7.4)$ & $2.8(0.7-11.8)$ & 0.106 \\
\hline Lymphocyte count, $\times 10^{9} / \mathrm{L}$ & $1.0(0.1-2.3)$ & $1.2(0.2-2.6)$ & $<0.05$ & $0.7(0.1-1.6)$ & $0.9(0.2-2.6)$ & $<0.01$ & $1.3(0.7-2.3)$ & $1.3(0.4-2.6)$ & 0.492 \\
\hline Platelet count, $\times 10^{9} / \mathrm{L}$ & $180.0(18.0-564.0)$ & $227.0(42.0-583.0)$ & $<0.01$ & $169.0(18.0-564.0)$ & $220.0(109.0-576.0)$ & $<0.05$ & $188.5(110.0-548.0)$ & $232.0(42.0-583.0)$ & 0.093 \\
\hline C-reactive protein, $\mathrm{mg} / \mathrm{L}$ & $14.1(0.1-212.0)$ & $11.4(0.1-204.5)$ & 0.307 & $48.6(0.1-212.0)$ & $26.1(0.1-204.5)$ & 0.677 & $7.4(3.1-111.0)$ & $9.8(0.4-126.0)$ & 0.817 \\
\hline D-dimer, mg/L & $0.5(0.2-9.7)$ & $0.5(0.1-20.0)$ & 0.750 & $1.2(0.2-9.7)$ & $0.9(0.1-20.0)$ & 0.424 & $0.4(0.2-6.4)$ & $0.4(0.2-8.7)$ & 0.455 \\
\hline Creatine kinase, $\mathrm{U} / \mathrm{L}$ & $79.0(8.8-12216.0)$ & $60.5(19.0-1260.0)$ & 0.167 & $104.0(8.8-12216.0)$ & $64.0(19.0-1214.0)$ & 0.081 & $52.5(28.0-206.0)$ & $59.0(19.0-1260.0)$ & 0.561 \\
\hline Lactate dehydrogenase, U/L & $243.0(2.2-880.0)$ & $241.0(3.5-908.0)$ & 0.766 & $334.0(2.2-880.0)$ & $299.0(3.5-743.0)$ & 0.324 & $198.0(2.5-417.0)$ & $226.0(121.0-908.0)$ & 0.142 \\
\hline
\end{tabular}




\begin{tabular}{|c|c|c|c|c|c|c|c|c|c|}
\hline Alanine aminotransferase, $\mathrm{U} / \mathrm{L}$ & $27.0(5.0-261.0)$ & $26.0(6.0-1933.0)$ & 0.214 & $35.0(5.0-259.0)$ & $31.0(7.0-1933.0)$ & 0.320 & $25.5(13.0-261.0)$ & $23.0(6.0-135.0)$ & 0.682 \\
\hline Aspartate aminotransferase, U/L & $29.5(13.0-213.0)$ & $26.0(8.0-8191.0)$ & 0.1031 & $35.5(14.0-213.0)$ & $34.0(8.0-8191.0)$ & 0.319 & $23.0(13.0-198.0)$ & $23.5(9.0-244.0)$ & 0.575 \\
\hline Blood urea nitrogen, $\mathrm{mmol} / \mathrm{L}$ & $4.5(1.6-48.1)$ & $4.1(1.5-19.1)$ & $<0.05$ & $5.0(2.3-48.1)$ & $4.4(1.5-19.1)$ & 0.041 & $3.9(1.6-9.4)$ & $3.8(1.7-13.7)$ & 0.568 \\
\hline Creatinine, $\mu \mathrm{mol} / \mathrm{L}$ & $71.7(37.1-1299.2)$ & $66.3(35.9-9435.0)$ & 0.062 & $71.7(37.1-1299.2)$ & $68.4(35.9-9435.0)$ & 0.245 & $72.0(40.3-133.6)$ & $63.4(39.4-229.1)$ & 0.265 \\
\hline
\end{tabular}

Abbreviations: CNS, central nerves system.

$P$ values indicate differences between patients with and without CNS. $P<0.05$ was considered statistically significant 
Table 4 Laboratory findings of COVID-19 patients with PNS symptoms

\begin{tabular}{|c|c|c|c|c|c|c|c|c|c|}
\hline & \multicolumn{3}{|c|}{ Total } & \multicolumn{3}{|c|}{ Severe } & \multicolumn{3}{|c|}{ Non-severe } \\
\hline & $\begin{array}{l}\text { With PNS } \\
\text { symptoms } \\
(\mathrm{n}=19)\end{array}$ & $\begin{array}{l}\text { Without PNS } \\
\text { symptoms } \\
(\mathrm{n}=195)\end{array}$ & $P$ & $\begin{array}{c}\text { With PNS } \\
\text { symptoms } \\
(\mathrm{n}=7)\end{array}$ & $\begin{array}{l}\text { Without PNS } \\
\text { symptoms } \\
(\mathrm{n}=81)\end{array}$ & $P$ & $\begin{array}{l}\text { With PNS } \\
\text { symptoms } \\
(\mathrm{n}=12)\end{array}$ & $\begin{array}{l}\text { Without PNS } \\
\text { symptoms } \\
(\mathrm{n}=114)\end{array}$ & $P$ \\
\hline \multicolumn{10}{|l|}{ Median (range) } \\
\hline White blood cell count, $\times 10^{9} / \mathrm{L}$ & $4.8(2.8-7.5)$ & $4.9(0.1-20.4)$ & 0.744 & $4.5(3.1-6.8)$ & $5.6(0.1-20.4)$ & 0.105 & $4.9(2.8-7.5)$ & $4.4(1.8-14.0)$ & 0.273 \\
\hline Neutrophil, $\times 10^{9} / \mathrm{L}$ & $2.8(1.5-5.4)$ & $3.0(0.0-18.7)$ & 0.740 & $2.6(1.5-5.3)$ & $4.1(0.0-18.7)$ & 0.099 & $2.9(1.9-5.4)$ & $2.5(0.7-11.8)$ & 0.214 \\
\hline Lymphocyte count, $\times 10^{9} / \mathrm{L}$ & $1.2(0.6-2.6)$ & $1.1(0.1-2.6)$ & 0.433 & $1.2(0.6-1.6)$ & $0.9(0.1-2.6)$ & 0.257 & $1.2(0.7-2.6)$ & $1.3(0.4-2.4)$ & 0.917 \\
\hline Platelet count, $\times 10^{9} / \mathrm{L}$ & $204.0(111.0-305.0)$ & $213.0(18.0-583.0)$ & 0.564 & $204.0(111.0-245.0)$ & $205.0(18.0-576.0)$ & 0.558 & $214.5(155.0-305.0)$ & $219.0(42.0-583.0)$ & 0.806 \\
\hline C-reactive protein, $\mathrm{mg} / \mathrm{L}$ & $12.0(3.1-81.0)$ & $12.3(0.1-212.0)$ & 0.446 & $7.5(3.1-76.4)$ & $43.7(0.1-212.0)$ & 0.134 & $13.0(3.1-81.0)$ & $8.8(0.4-126.0)$ & 0.598 \\
\hline D-dimer, mg/L & $0.4(0.2-9.5)$ & $0.5(0.1-20.0)$ & 0.399 & $0.5(0.2-9.5)$ & $1.3(0.1-20.0)$ & 0.272 & $0.4(0.2-4.5)$ & $0.4(0.2-8.7)$ & 0.989 \\
\hline Creatine kinase, $\mathrm{U} / \mathrm{L}$ & $67.0(32.0-1214.0)$ & $64.0(8.8-12216.0)$ & 0.413 & $105.0(32.0-1214.0)$ & $83.0(8.8-12216.0)$ & 0.761 & $66.0(42.0-171.0)$ & $57.5(19.0-1260.0)$ & 0.291 \\
\hline
\end{tabular}




\begin{tabular}{|c|c|c|c|c|c|c|c|c|c|}
\hline Lactate dehydrogenase, $\mathrm{U} / \mathrm{L}$ & $205.0(2.5-517.0)$ & $242.0(2.2-908.0)$ & 0.284 & $170.0(46.0-517.0)$ & $309.0(2.2-880.0)$ & 0.050 & $254.0(2.5-481.0)$ & $215.0(2.9-908.0)$ & 0.669 \\
\hline Alanine aminotransferase, $\mathrm{U} / \mathrm{L}$ & $26.0(5.0-116.0)$ & $27.0(6.0-1933.0)$ & 0.695 & $19.0(5.0-80.0)$ & $35.0(8.0-1933.0)$ & 0.232 & $26.0(8.0-116.0)$ & $23.0(6.0-261.0)$ & 0.555 \\
\hline Aspartate aminotransferase, & $22.0(8.0-115.0)$ & $27.0(9.0-8191.0)$ & 0.288 & $22.0(8.0-53.0)$ & $35.5(12.0-8191.0)$ & 0.126 & $22.0(14.0-115.0)$ & $23.5(9.0-244.0)$ & 1.000 \\
\hline Blood urea nitrogen, $\mathrm{mmol} / \mathrm{L}$ & $4.1(1.6-8.8)$ & $4.1(1.5-48.1)$ & 0.764 & $4.2(3.5-8.8)$ & $4.7(1.5-48.1)$ & 0.963 & $3.7(1.6-5.3)$ & $3.9(1.7-13.7)$ & 0.660 \\
\hline Creatinine, $\mu \mathrm{mol} / \mathrm{L}$ & $62.5(48.1-121.4)$ & $68.3(35.9-9435.0)$ & 0.455 & $71.4(58.3-121.4)$ & $71.7(35.9-9435.0)$ & 0.717 & $59.9(48.1-77.3)$ & $66.6(39.4-229.1)$ & 0.235 \\
\hline
\end{tabular}

Abbreviations: PNS, peripheral nerves system.

$P$ values indicate differences between patients with and without PNS. $P<0.05$ was considered statistically significant. 
Table 5 Laboratory findings of COVID-19 patients with muscle injury

\begin{tabular}{|c|c|c|c|c|c|c|c|c|c|}
\hline & \multicolumn{3}{|c|}{ Total } & \multicolumn{3}{|c|}{ Severe } & \multicolumn{3}{|c|}{ Non-severe } \\
\hline & $\begin{array}{l}\text { With muscle } \\
\text { injury } \\
(\mathrm{n}=23)\end{array}$ & $\begin{array}{c}\text { Without muscle } \\
\text { injury } \\
(\mathrm{n}=191)\end{array}$ & $P$ & $\begin{array}{l}\text { With muscle } \\
\text { injury } \\
(\mathrm{n}=17)\end{array}$ & $\begin{array}{c}\text { Without muscle } \\
\text { injury } \\
(\mathrm{n}=71)\end{array}$ & $P$ & $\begin{array}{l}\text { With muscle injury } \\
\qquad(\mathrm{n}=6)\end{array}$ & $\begin{array}{c}\text { Without muscle } \\
\text { injury } \\
(\mathrm{n}=120)\end{array}$ & $P$ \\
\hline \multicolumn{10}{|l|}{ Median (range) } \\
\hline White blood cell count, $\times 10^{9} / \mathrm{L}$ & $6.0(2.3-20.4)$ & $4.8(0.1-15.6)$ & 0.248 & $6.7(2.3-20.4)$ & $5.2(0.1-15.6)$ & 0.269 & $4.3(2.4-6.1)$ & $4.5(1.8-14.0)$ & 0.618 \\
\hline Neutrophil, $\times 10^{9} / \mathrm{L}$ & $4.3(0.9-18.7)$ & $2.9(0.0-13.0)$ & 0.031 & $5.5(0.9-18.7)$ & $3.5(0.0-13.0)$ & 0.076 & $2.6(1.1-4.5)$ & $2.6(0.7-11.8)$ & 0.945 \\
\hline Lymphocyte count, $\times 10^{9} / \mathrm{L}$ & $0.9(0.1-2.6)$ & $1.2(0.1-2.6)$ & 0.002 & $0.8(0.1-2.6)$ & $0.9(0.1-2.5)$ & $<0.05$ & $1.2(1.0-2.1)$ & $1.3(0.4-2.6)$ & 0.846 \\
\hline Platelet count, $\times 10^{9} / \mathrm{L}$ & $185.0(82.0-436.0)$ & $215.0(18.0-583.0)$ & 0.224 & $182.0(82.0-436.0)$ & $209.0(18.0-576.0)$ & 0.407 & $223.0(122.0-304.0)$ & $219.0(42.0-583.0)$ & 0.688 \\
\hline C-reactive protein, $\mathrm{mg} / \mathrm{L}$ & $56.0(0.1-212.0)$ & $11.1(0.1-204.5)$ & $<0.001$ & $70.8(0.1-212.0)$ & $21.0(0.1-204.5)$ & 0.078 & $18.1(9.7-126.0)$ & $8.1(0.4-123.0)$ & $<0.05$ \\
\hline D-dimer, mg/L & $1.3(0.2-20.0)$ & $0.5(0.1-20.0)$ & $<0.05$ & $1.7(0.2-20.0)$ & $0.6(0.1-20.0)$ & 0.120 & $0.4(0.2-1.3)$ & $0.4(0.2-8.7)$ & 0.679 \\
\hline Creatine kinase, $\mathrm{U} / \mathrm{L}$ & $400.0(203.0-12216.0)$ & $58.5(8.8-212.0)$ & $<0.001$ & $\begin{array}{l}525.0(203.0- \\
12216.0)\end{array}$ & $64.0(8.8-212.0)$ & $<0.001$ & $231.0(206.0-1260.0)$ & $57.5(19.0-184.0)$ & $<0.001$ \\
\hline
\end{tabular}




\begin{tabular}{|c|c|c|c|c|c|c|c|c|c|}
\hline Lactate dehydrogenase, U/L & $415.0(147.0-743.0)$ & $229.0(2.2-908.0)$ & $<0.001$ & $\begin{array}{l}442.0(147.0- \\
743.0)\end{array}$ & $285.0(2.2-880.0)$ & $<0.01$ & $315.0(210.0-666.0)$ & $213.0(2.5-908.0)$ & $<0.05$ \\
\hline Alanine aminotransferase, $\mathrm{U} / \mathrm{L}$ & $44.0(14.0-173.0)$ & $25.0(5.0-1933.0)$ & $<0.01$ & $50.0(14.0-173.0)$ & $30.0(5.0-1933.0)$ & $<0.05$ & $28.0(16.0-63.0)$ & $23.0(6.0-261.0)$ & 0.495 \\
\hline Aspartate aminotransferase, $\mathrm{U} / \mathrm{L}$ & $46.0(22.0-209.0)$ & $25.0(8.0-8191.0)$ & $<0.001$ & $53.0(26.0-209.0)$ & $31.0(8.0-8191.0)$ & $<0.001$ & $34.5(22.0-60.0)$ & $23.0(9.0-244.0)$ & 0.065 \\
\hline Blood urea nitrogen, $\mathrm{mmol} / \mathrm{L}$ & $4.8(2.0-48.1)$ & $4.1(1.5-19.1)$ & $<0.05$ & $4.8(2.4-48.1)$ & $4.6(1.5-19.1)$ & 0.256 & $5.9(2.0-10.6)$ & $3.8(1.6-13.7)$ & 0.264 \\
\hline Creatinine, $\mu \mathrm{mol} / \mathrm{L}$ & $80.5(43.7-1299.2)$ & $66.9(35.9-9435.0)$ & $<0.01$ & $81.5(43.7-1299.2)$ & $68.4(35.9-9435.0)$ & $<0.05$ & $77.4(60.7-229.1)$ & $65.1(39.4-215.3)$ & 0.050 \\
\hline
\end{tabular}

$P$ values indicate differences between patients with and without muscle injury. $P<0.05$ was considered statistically significant. 